\title{
LAS VOCES NARRATIVAS EN LA OBRA DOCUMENTAL AGRARIA DE JOSÉ NECHES ${ }^{1}$
}

\author{
THE NARRATIVE VOICES IN THE AGRARIAN DOCUMENTARY \\ WORK OF JOSÉ NECHES
}

\author{
Ana MELENDO CRUZ \\ Universidad de Córdoba \\ aa1mecra@uco.es
}

\begin{abstract}
Resumen: La aproximación a la obra documental de José Neches resulta decisiva en la comprensión del documental rural en España, no solo desde un punto de vista histórico, sino también desde una perspectiva plástica. El carácter pedagógico que los define necesita del uso de algunos artificios narrativos que posibiliten el pacto de verosimilitud entre el emisor y el receptor que anima a todo texto documental. Por eso, este trabajo quiere ocuparse de la lectura narratológica de las diferentes voces narrativas, que irrumpen en la filmografía nechesiana, para arrojar luz sobre las distintas funciones que en estos textos desempeñan.
\end{abstract}

Palabras Clave: Cine documental. José Neches. Narratología. Voz

\footnotetext{
${ }^{1}$ Este trabajo ha sido realizado en el marco del proyecto de investigación La contribución de José Neches al documental agrario español del franquismo (1945-1976) del Programa Estatal de Fomento de la Investigación Científica y Técnica de Excelencia del Ministerio de Economía y Competitividad (referencia HAR2016-77137-P). Convocatoria 2016. Investigadores principales: Ana Melendo Cruz y Pedro Poyato Sánchez.
} 
narrativa.

Abstract: The approximation to the agrarian documentary work of José Neches is decisive for the comprehension of the rural documentary in Spain, not only from a historical point of view but, also, from a visual perspective. The pedagogical character which defines his work uses some narrative tools that make possible the verisimilitude deal between the sender and the receiver which enlivens every documentary text. Therefore, this work aims to address the narratological lecture of the different narrative voices that burst into Neches' filmography to shed light on the many functions this texts carry.

Key Words: Documentary cinema. José Neches. Narratology. Narrative voice.

\section{INTRODUCCIÓN}

La obra fílmica de José Neches, que abarca desde 1947 a 1976, recientemente recuperada, restaurada y distribuida por el Departamento del Servicio de Publicaciones, desde el área de Archivos, Biblioteca y Mediateca del Ministerio de Agricultura y Pesca, Alimentación y Medio Ambiente, se convierte en fundamental a la hora de estudiar el documental agrario español. Investigaciones previas, referidas a la obra de otros documentalistas preocupados por el ámbito rural, como el marqués de Villa Alcázar o Pascual Carrión, así lo han demostrado ${ }^{2}$. La importancia de estos textos cinematográficos radica en su valor como documento histórico, capaz de atestiguar los hechos del pasado, pero también en la forma fílmica contenida en ellos, dos aspectos que, como se verá más adelante, están íntimamente relacionados en este caso. Y es que, en esa reconstrucción de lo ocurrido a través de la imagen cinematográfica, que nunca resulta fácil por

${ }^{2}$ Véanse Gómez Tarín y Parejo (2013) y Ortega Arjonilla (2017). 
los discursos dispares que de ella se desprenden, es posible leer las marcas de un ayer que nos permiten conocer e identificar las diferencias, sobre todo teniendo en cuenta que los fondos documentales en los que se centra nuestro estudio están producidos por organismos oficiales, gubernativos o dependientes de ellos, existentes en el franquismo. Es evidente que nuestro trabajo no quiere ocuparse de narrativas que desde el presente evocan el pasado, sino de otras que nacen en el pasado y que van a ser revisadas desde el presente. Se trata, por tanto, de la interpretación temporal de unos valores que forman parte de la vida de una sociedad, pero siempre teniendo en cuenta que, como asegura Eco, un texto, tal como aparece en su superficie (o manifestación) lingüística, "representa una cadena de artificios expresivos que el destinatario debe actualizar" (1987: 73). Parece inevitable entonces que, en esa revisión, el destinatario del que habla Eco, se enfrente a los textos del pasado con sus propias normas y valores ${ }^{3}$ para convertirse así, como señala Iser, en:

[...] un potencial de efectos, que solo es posible actualizar en el proceso de lectura [...] Pues la obra es más que el texto, puesto que solo cobra su vida en la concreción y, por su parte, esta no se halla totalmente libre de las aptitudes que introduce el lector, aun cuando tales aptitudes sean activadas según los condicionantes del texto (1987: 11-44).

Por otra parte, Gómez Benito afirma que:

La historia se ha basado en la primacía de lo escrito. Y tiene que afrontar el hecho de la utilización de ese testimonio de lo "visto" que es la imagen. En las manos del historiador, la imagen fotográfica [o cinematográfica en este caso] puede tener varios usos. Los dos principales tienen que ver con dos usos fundamentales de la historia: el registro de lo que ha sucedido y la narración de lo sucedido (2015:

${ }^{3}$ Jauss (1986) lo llama horizonte de expectativas. 
$312)$.

Es precisamente en ese narrar lo sucedido donde entra en juego la forma de hacer de un cineasta, este que nos ocupa, que utiliza el documental científico, divulgativo y formativo, con la finalidad de comunicar y mostrar, mediante un mensaje seductor, los abundantes conocimientos y destrezas, relacionados con el mundo agrícola, manejando para ello algunos de los mecanismos procedentes de la ficción que, sin embargo, le permiten lograr, como veremos, la confianza entre el emisor y el receptor. Pues bien, de todos los artificios ficcionales puestos en juego en la filmografía de Neches queremos ocuparnos en este estudio de las voces narrativas por las operaciones de sentido que producen en estos textos cinematográficos y la polifonía contextual, en términos de Bajtín (1991: 149), que de ellas se desprende. Efectivamente, a partir del análisis de algunos fragmentos seleccionados trataremos de dar cuenta de la presencia y la funcionalidad que desempeñan los distintos narradores que aparecen en la obra nechesiana, por cuanto suponen una componente ineludible en la forma narrativa de estos cuarenta y siete documentales agrarios. No obstante, antes de entrar en materia, consideramos conveniente aproximarnos, aunque de manera sucinta, a la figura de José Neches con el objetivo de hacer más comprensibles algunos de los aspectos que desarrollaremos con posterioridad.

\section{BREVE APROXIMACIÓN A LA FIGURA DE JOSÉ NECHES $^{4}$}

La llegada de José Neches al Servicio de Extensión Agraria (en adelante SEA), lugar donde desempeña su labor cinematográfica más fructífera, se produce en 1959, después de que se le concede el reingreso

${ }^{4}$ Los datos biográficos del cineasta pueden consultarse en la siguiente dirección: http://www.mapama.gob.es/es/ministerio/archivos-bibliotecas-mediateca/mediateca/ biofilmografia-neches_tcm30-379746.pdf [05/06/2018] 
al Ministerio de Agricultura en el Organismo Autonómico de Extensión Agraria como Técnico en Cinematografía. Es cierto que su carrera como cineasta comienza unos años antes, siempre bajo la supervisión del Ministerio de Agricultura, concretamente en 1945 con la película Cortijo andaluz, y a partir de entonces realiza, ininterrumpidamente, más de cuarenta películas documentales, relacionadas con el mundo rural, para el Ministerio de Agricultura y otros Organismos. En todo caso, su amor por el cine y el espectáculo no hemos de verlo solamente ligado al documental rural. Por el contrario, durante mucho tiempo se mantiene unido al mundo del espectáculo a través de su afición al flamenco y como empresario de espectáculos y salas de cine, gestionando varios de estos locales en la Gran Vía Madrileña. También realiza alguna incursión como director en el cine de ficción a partir de su estancia en Guinea con la intención de mostrar a la sociedad cómo era la vida en una de las últimas colonias españolas. De ahí surge el título Afan Evu (1945) que es una adaptación de la obra de 1943 de Wenceslao Fernández Flores: El bosque maldito ${ }^{5}$.

No obstante, en su interés por promover la docencia a través del cine, forma, en todas las regiones españolas, a un grupo de Agentes de Extensión Agraria que se especializan en la realización de cine, sobre todo de cine documental. Pero no debemos olvidar que los organismos institucionales en los que desempeña su tarea como cineasta y docente están controlados por un estado fascista que vigila muy de cerca cada uno de los movimientos de aquellos que, bajo el paraguas de ciertas acciones educativas que se llevan a cabo durante los cuarenta años de dictadura, intentan, a su modo, liberar del atraso y la miseria cultural, humana y profesional a los habitantes del mundo rural. Precisamente el SEA nace con la intención de ayudar a los agricultores en el progreso de un mundo cambiante, el agrícola, incorporando, de una manera afectiva, a las familias, los jóvenes y, en definitiva, a las comunidades rurales, a las tareas

\footnotetext{
${ }^{5}$ Para obtener más información al respecto, consultar: Ministerio de Agricultura, Alimentación y Medio Ambiente, José Neches Nicolás. Madrid: Ministerio de Agricultura, Alimentación y Medio Ambiente (2017: 11-13).
} 
de desarrollo. Se trata de que el agricultor se encuentre respaldado, tal y como explica Juan Manuel García Bartolomé:

[...] por la solvencia técnica de un organismo que trabaja permanentemente a su lado. La consideración de los agricultores no solo como beneficiarios fundamentales del desarrollo, sino como agentes de la creación y evolución del mismo [...] Desde una perspectiva actual, puede afirmarse que el SEA fue un organismo movilizador de recursos y voluntades para promover el progreso agrario y el desarrollo de las comunidades rurales, que aplicó enfoques teóricos y metodológicos que resultaron innovadores en las políticas públicas (2009: 9).

Estas palabras de García Bartolomé nos permiten reconducir este estudio hasta la aproximación de un cine documental agrario que ha forjado, como veremos, una representación muy nítida acerca de la situación de las comunidades rurales en la época franquista, utilizando para ello unos instrumentos escriturales que nos permiten completar y actualizar el sentido que emana de unos vestigios que se convierten en herramientas para comprender por un lado, algunas particularidades del destino histórico de una época, y por otro, el legado artístico de su creador.

\section{PRESUPUESTOS TEÓRICOS}

Si partimos de la premisa de que el principal objetivo de la obra nechesiana es establecer puentes pedagógicos entre un emisor instruido en materia agrícola ${ }^{6}$ y un receptor dispuesto a recibir estos conocimientos, podemos plantear, entonces, el estudio de los textos cinematográficos de Neches como objetos de comunicación que nos obligan, desde una

\footnotetext{
${ }^{6}$ Partiendo de esta idea, conviene puntualizar que los documentales producidos por el Ministerio de Agricultura en época franquista conllevan otros motivos ideológicos y propagandísticos que van a más allá de los conocimientos puramente agropecuarios.
} 
perspectiva pragmática, a enfrentarnos a las relaciones que entablan emisores, receptores y texto, relaciones que habría que considerarlas no solo dentro del texto sino fuera de él. De esta forma, y con la intención de arrojar luz sobre las huellas de la enunciación, en el sentido apuntado por Genette (1989: 273), que determinan, en gran medida, la escritura nechesiana, se hace necesario dilucidar quién cuenta la historia, a quién se la cuenta y cómo se la cuenta, en la obra del cineasta zamorano; a la vez que convendría, por la notable carga ideológica que estas películas llevan aparejada, profundizar en las relaciones supratextuales que implican al emisor y a los receptores reales de estos jugosos documentales.

Ciertamente, los estudios sobre narratología en el cine derivan de los hallazgos diseñados para el modelo literario por Genette precisamente por el alto nivel de equivalencia que se evidencia entre uno y otro medio de expresión. Sin embargo, solo hay que pensar en el doble registro que el cine presenta, icónico y verbal, para comprender la distancia que aparece entre ambos campos de trabajo. Desde esta perspectiva, Brian Henderson explica en su artículo "Tense, Mood an Voice in Film”, cómo aún encontrándose esas correspondencias entre literatura y cine existen ciertas áreas de dificultad en la categoría, sobre todo de la voz, porque, según él, "no tiene un análogo adecuado en el cine"7.

Partimos aquí de la idea de que la imagen cinematográfica se constituye en un significante ${ }^{8}$ de diversa entidad respecto a la palabra, por mucho que en los dos casos quien realiza la enunciación sea una fuente ficticia. Es por lo que algunos narratólogos del cine, como Gaudreault y Jost, señalan que la voz cinematográfica no puede entenderse como la literaria porque, "los relatos fílmicos, como audiovisuales que son, implican la presencia de dos capas superpuestas de narratividad: mostración y narración” (1995: 63-64). El trabajo de Stam, Burgoyne y

\footnotetext{
${ }^{7}$ Recogido en: Stam, Burgoyne y Flitterman-Lewis (1999: 119).

${ }^{8}$ Recit en términos de Genette. Stam, Burgoyne y Flitterman Lewis lo definen como el discurso verbal o cinemático que transporta el mundo de la historia al espectador, por ejemplo, la modelización real de los planos en una película (1999: 118).
} 
Flitterman-Lewis (1999) viene a completar las ideas de Branigan (1984), Black (1986) y, sobre todo, de Gaudreault y Jost (1990) que afirman que puede existir un narrador extradiegético, que tiene el control de todos los mecanismos discursivos que aparecen en el filme, y que se corresponde con un narrador fundamental ${ }^{9}$ que sería el responsable último de la enunciación. Este narrador fundamental es definido con posterioridad por Stam, Burgoyne y Flitterman-Lewis como un narrador cinemático cuya función es proporcionar, junto a otros elementos propios del cine, a través de una gran variedad de canales y códigos, información sobre la historia (1999: 127). Los autores citados secundan, por tanto, las teorías establecidas por otros como Chatman, Gaudreault, Casetti y Gunning que defienden ${ }^{10}$ :

[...] el concepto de narrador cinemático como esencial para la comprensión del proceso y la estructura de la comunicación narrativa del cine. De acuerdo con estos autores, la presencia de un narrador extradiegético, manifiesto o implícito, es una necesidad lógica, que dispone los principios directrices por medio de los cuales entendemos la jerarquía de los roles narrativos, determinamos la cualidad de verdad y autenticidad en el mundo ficcional, y comprendemos los hechos representados del cine como una especie de "mensaje" (Stam, Burgoyne y Flitterman-Lewis, 1999: 133).

\footnotetext{
${ }^{9}$ Esto es un narrador que controla el conjunto de técnicas cinemáticas, incluyendo la $\mathrm{voz}$ over (Stam, Burgoyne y Flitterman-Lewis, 1999: 121).

${ }^{10}$ También Pedro Poyato ha señalado que nos encontramos "[...] con una instancia extradiegética, impersonal, sin voz (en el sentido literal de la expresión) y que puede manifestarse en el relato a través de los delegados, las voces narradoras, o de marcas definidas a partir de la conjugación de los distintos registros fílmicos [...] Los narradores intradiegéticos, o delegados en la diégesis del narrador cinemático: son los encargados de dar cuenta, al modo de participantes o testigos, del mundo ficcional” (2013: 100).
} 
Llegados a este punto parece clara la urdimbre teórica en la que nuestra investigación quiere fundamentarse. Sin embargo, todavía hemos de referirnos a la dificultad que conlleva trasladar el análisis de las voces narrativas al estudio del cine documental. La investigadora Aida Vallejo ha señalado cómo:

En el marco concreto de los estudios dedicados al cine documental, el análisis de las formas de la enunciación se ha visto condicionado, en primer lugar, por la falta de interés de muchos autores hacia las herramientas de narratología y, en segundo lugar, porque los debates centrales en torno al documental se han dirigido más a cuestiones relacionadas con su carácter informativo y/o su relación con conceptos como la realidad o la verdad que a su propia construcción formal (2013: 7).

El cine documental se ha visto confrontado, de esta manera, al cine de ficción, tildándolo, en muchos casos de cine no narrativo (Bordwel y Thompson, 1997: 47-48), por entenderse que el cine narrativo es sinónimo de cine de ficción (Nichols, 1985: 259). Esa negación del uso de la narrativa en los textos documentales puede deberse, como apunta Plantinga, a:

[...] la extendida idea de que el documental, como representación de la realidad, debería tomar una forma "en concordancia" con su tema. Lo que esta afirmación suele querer decir es que, de alguna manera, el documental debería copiar, trazar o imitar la realidad no simplemente en su modelo de lo real (el mundo proyectado) sino en su propia presentación formal (1997: 124).

Pues bien, con este armazón teórico queremos aproximarnos a la obra documental de José Neches, no solo para desmontar la anterior aseveración, sino para comprobar cómo la forma narrativa que adopta el texto nechesiano deviene en categoría formal que adquiere una doble 
funcionalidad vinculada, por un lado, al discurrir de los acontecimientos, y por otro, a la consolidación de un sistema estético propio, en el sentido dado a estos términos por Santos Zunzunegui (2001: 52).

\section{DE LA DIVERSIDAD DE LAS FORMAS NARRATIVAS EN LOS DOCUMENTALES DE JOSÉ NECHES}

El primer detalle al que debemos referirnos, al tratar de comprender el significado que emana del uso de las voces narrativas en la obra documental de Neches, es que existe la voluntad por parte del cineasta, así lo demuestra el conjunto de su obra, de establecer diversos modelos de documentales con los que poder aproximarse al público al que estos van dirigidos. Basándonos en algunas de las categorías dispuestas por Nichols (1997), en cuanto a los distintos modos de representación de la realidad ${ }^{11}$, trataremos de ver en lo que sigue, a partir del análisis de un ramillete de películas seleccionadas para tal fin, cómo maneja el cineasta zamorano el lenguaje audiovisual como instrumento narrativo con el que trazar lazos de comunicación entre el emisor y el receptor apoyándose, en todo momento, en el deseo de credibilidad. Efectivamente, el cineasta no duda en utilizar los planteamientos básicos del documental de observación ${ }^{12}$ en títulos como, Cuidado de los combustibles (1964) o Plantación de frutales (1964), según las categorías instauradas por Nichols, en los que la cámara se limita a registrar lo que podríamos denominar una master class dirigida

\footnotetext{
11“Entendemos como realidad, en términos muy generales, un campo referencial que en todo caso abarca el mundo empírico, sensible, habitable, pero que también se dilataría hacia los territorios de lo conceptual, simbólico, sentimental, imaginario, etc., esto es, todo aquello que puede afectar (o verse afectado por) la acción física o mental del hombre en su dimensión tanto individual como social" (Monterde, 2001: 15-16).

${ }^{12}$ "Los documentales de observación son los que Erik Barnauw considera cine directo y los que otros como Stephen Mamber describen como cinema verité [...] La presencia de la cámara 'en el lugar' atestigua su presencia en el mundo histórico: su fijación sugiere un compromiso con lo inmediato, lo íntimo y lo personal que es comparable a lo que podría experimentar un auténtico observador/ participante (sin el recurso ilimitado de la dinamización del tiempo y el espacio que permite el cine)" (Nichols, 1997: 72 y 74).
} 
a los agricultores, ganaderos y Agentes de Extensión Agraria. Pero si el objetivo perseguido así lo requiere, Neches renuncia a las leyes fijadas por el cine de no ficción para recurrir a parámetros puramente ficcionales, entendiendo que, como dice Nichols:

El documental nos dirige al mundo de la realidad brutal al mismo tiempo que intenta interpretarlo, y la expectativa de que lo vaya a hacer supone una intensa diferencia con respecto a la ficción. Los documentales nos dirigen hacia el mundo pero también siguen siendo textos. Por tanto comparten todas la implicaciones concomitantes del estatus construido, formal e ideológicamente modulado, de la ficción. El documental se diferencia, sin embargo, en que nos pide que lo consideremos como una representación del mundo histórico en vez de cómo una semejanza o imitación del mismo (1997: 154).

Siguiendo los planteamientos adoptados por Nichols, con nuestra aproximación a los documentales de Neches, a partir del estudio de las voces narrativas que se dan cita en su obra, veremos cómo los textos no ficcionales no difieren de las ficciones en su construcción como textos sino en las representaciones que hacen del mundo a través de similitudes fotográficas y auditivas del mismo, abordando el mundo en el que vivimos en lugar del mundo en el que imaginamos vivir.

\subsection{Los documentales expositivos de Neches y la voz over}

Como hemos dicho más arriba, la voz over es una de esas categorías que escapa a las estudiadas por Genette, desde el punto de la vista de los estudios cinematográficos, y que, sin embargo, se traduce en esencial para nuestro estudio porque en la obra nechesiana se barajan, pues, cada una de las modalidades a las que esta puede inscribirse ${ }^{13}$, sobre todo en

\footnotetext{
${ }^{13} \mathrm{La}$ voz en over puede ser homodiegética — que da lugar a la llamada narración en
} 
los documentales de carácter expositivo en los que sin el anclaje de la palabra las imágenes pueden flotar a la deriva. Y es que, según la teoría desarrollada por Nichols:

El texto expositivo se dirige al espectador directamente, con intertitulos o voces que exponen una argumentación acerca del mundo histórico [...] Los textos expositivos toman forma en torno a un comentario dirigido hacia el espectador, las imágenes sirven como ilustración o contrapunto [...] La retórica de la argumentación del comentarista desempeña la función de dominante textual, haciendo que el texto avance al servicio de su necesidad de persuasión (1997: 68).

Indudablemente, si atendemos a los dos primeros documentales realizados por Neches, a saber, Cortijo andaluz (1945) y Reses bravas (1945), podemos constatar que ambos se constituyen en ejemplos claros de lo que venimos exponiendo. En los dos casos nos encontramos con un narrador heterodiegético que marca el ritmo del discurso a partir de un lenguaje, de naturaleza poética, mediante el cual revela información sobre el mundo que desea mostrar. La voz over, acompañada por el sonido profundo de una guitarra flamenca, introduce al espectador, de igual modo, en esa construcción típica del hábitat rural de la zona meridional de España que es el cortijo, que en el ambiente que rodea a la ganadería y al toro de lidia con palabras como las que siguen: "En la tierra llana, oscura y esponjosa, la recortada silueta del cortijo andaluz es en su blancura hiriente, en contraste cromático con el añil del cielo, castillo no de bélica finalidad sino de paz y de trabajo" o: "Brillan los terneros en el prado

primera persona- y heterodiegética — que da lugar al relato en tercera persona-. A su vez, la voz en over homodiegética puede constituirse, según Kozloff (1988: 97-99), en narrador marco, que es aquel no visualizado que comienza su narración con las primeras imágenes de la película; o en narrador insertado, que comienza a narrar después de que la historia ha empezado y es visualizado en el acto de narración. 
como abalorios de azabache desprendidos del corpiño de la novia que en la noche de luna voló a pelar la pava".

La primera de estas dos películas trata de evidenciar cómo es la vida de aquellos que habitan ese microcosmos social que se genera en torno a tan emblemático lugar. Una sucesión de planos, engarzados por el montaje, presentan al cortijo como un emplazamiento de serenidad y trabajo a la vez que resaltan las zonas más representativas del mismo, tales como el jardín, que ayuda a alimentar el espíritu a través de las fragancias que de él emanan, o la capilla, espacio en el que, según la voz over, "van las miradas en señal del perdón y buscando la protección divina". Así mismo, se da cuenta de la vivienda señorial y del patio, con un arriate que el narrador describe cargado de flores, y que, según él, "pregona la sensibilidad femenina".

En la segunda, las imágenes muestran la extraordinaria nobleza y elegancia de unos animales que son conducidos por hombres que exhiben su valor cabalgando entre las reses bravas. Garrocheros y herraderos exponen su fuerza y su inteligencia, así se pone de manifestó cuando el narrador explica que, "el herradero reconoce como norma que más vale maña que fuerza”, mientras los ganaderos observan el varonil espectáculo. De este modo podemos observar cómo todos los detalles específicos que anclan expresivamente las imágenes proceden de la narración en off, de tal forma que solo esa voz over es capaz de transmutar en el decir ${ }^{14}$ la aparente inocencia de las imágenes en un mensaje cuya cualidad moralizadora

\footnotetext{
${ }^{14}$ Así, nos parece importante destacar la reflexión sobre "el decir" y "el mostrar" realizada por la profesora Sarah Kozloff en su artículo "Algunas cuestiones sobre el decir y el mostrar" en el que explica que: "El uso constante de la expresión 'voz de Dios' merece dos comentarios. Primero, tipificar los narradores en off como divinos u omniscientes implica ignorar las propias películas y sus pruebas. En los años treinta, Westbrook Van Voorhis, el narrador de los noticiarios March of Time, hablaba con gran autoridad, sin dar lugar a objeciones: hoy en día sus comentarios suenan acartonados, si no ridículamente risibles. Pero muchos de los narradores de documentales de la Segunda Guerra Mundial, que son ahora desestimados por su supuesta pomposidad y omnisciencia, eran en realidad mucho más vacilantes, medidos e irónicos de lo que se recuerda generalmente" (2013: 46).
} 
permite al narrador introducir ciertos parámetros de corte ideológico, que tienen que ver con la diferenciación de géneros o la importancia de la iglesia católica, entre otros, institucionalizados por el régimen franquista.

Pero la riqueza cromática que ofrece la voz over en estos documentales expositivos de Neches, ya lo decíamos, es muy variada. Por eso, si atendemos ahora a otra de las películas del cineasta podremos observar cambios sustanciales al respecto. Así, en Concurso nacional de tractoristas (1959), los toros han sido sustituidos por tractores que aparecen en escena acompañados por la música extradiegética de un pasodoble, como si el espectador hubiera de asistir a la retransmisión de una corrida de toros. Los vehículos dinamizan la composición a través de sus brillantes colore ${ }^{15}$ mientras el discurso de carácter lírico del narrador es reemplazado aquí por la conocida voz de Matías Prats. La voz over se inscribe en el texto en cuestión a partir del popular grano tonal del locutor de televisión, quien introduce al espectador en la IV Feria Internacional del Campo al estilo de los documentales de NO-DO ${ }^{16}$, es decir, con un tono marcadamente periodístico. Las imágenes, por su parte, confeccionan una escritura destinada a acompañar a quien, hasta el momento, parece un narrador heterodiegético. Prueba de ello son los dos carteles en los que se detiene la cámara para dar fe de las propias palabras que viene pronunciando Matías Prats (Figura 1). Sin embargo, mediante un corte de montaje, irrumpe en la pantalla la imagen del famoso periodista (Figura 2), de tal forma que la voz over se descubre ahora como voz $i n^{17}$, el narrador heterodiegético se convierte entonces en un narrador-reportero, es decir, en un narrador-personaje, que incrementa la relación entre narrador y narratario desde el momento en que los planos subjetivos que se suceden en la pantalla, a partir de su aparición en el universo narrativo, recuerdan

\footnotetext{
${ }^{15}$ La película muestra los avances tecnológicos que obran en ella y abandona el blanco y negro de las anteriores cintas para explorar el mundo del color.

${ }^{16}$ No podemos perder de vista que este documental trata de retransmitir unos hechos que encajan con la política interna del NO-DO, noticiario que funciona como referente, en muchos casos, de otros documentales que se realizan bajo el amparo gubernamental.

${ }^{17}$ La que se pronuncia en el propio campo según la definición de Kozloff (1998).
} 
a este último que está viendo lo que acontece a través de los ojos de quien está relatando la historia.
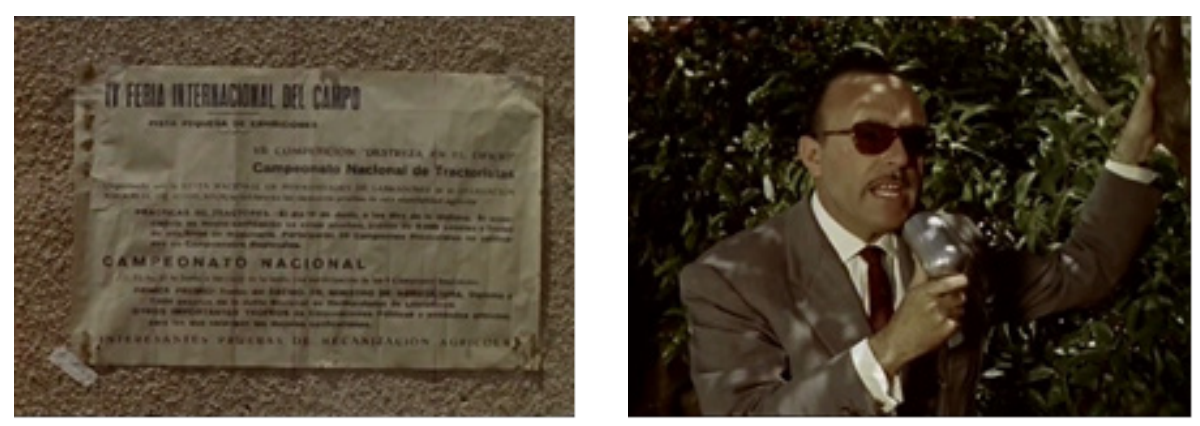

Figuras 1 y 2. Concurso nacional de Tractoristas (Neches, 1959)

Podríamos decir, entonces, que este narrador televisivo está más próximo al tipo definido por Genette como narrador homodiegético, puesto que el narrador obtiene la información de lo que cuenta a través de su participación en la diégesis. Al hilo de este enunciado conviene considerar la figura del narrador-reportero ${ }^{18}$ en los términos sugeridos al respecto por Jesús García Jiménez:

Es una figura intermedia entre el narrador autodiegético y el heterodiegético. Se diferencia de aquél en que, siendo personaje como él, no es el personaje central de la historia. Se diferencia del heterodiegético en que participa de la diégesis, y el conocimiento de aquello que cuenta es, por tanto, un conocimiento directo (1993: 116).

La presencia de Matías Prats responde, por tanto, a una función enfática destinada a destacar determinados acontecimientos que tienen

\footnotetext{
${ }^{18}$ Este tipo de narrador recuerda al denominado por Friedman el yo-testigo, en su ya clásico artículo de 1955, "The Point of View in Fiction: The Development of a Critical Concept". Se trata de un enunciador que, desde dentro de la diégesis, habla, claro está, en primera persona y ha presenciado los hechos que cuenta, pero no los ha protagonizado.
} 
lugar en el transcurrir del relato. Por ejemplo, cuando dice mientras mira y señala con su mano enérgica hacia el fuera de campo: "Nos dicen que el paso más difícil es el número trece ¡Atención a él!”; o cuando intentando alcanzar con su mirada lo que sucede a lo lejos anima de esta forma a los concursantes: “iAdelante, Lérida. A ceñirse y a ajustarse. Que rocen nuestros alamares el tractor!"; o, por fin, cuando, realiza un barrido con sus ojos en el fuera de campo y proclama así al ganador: “¡Y aquí llega el vencedor después de su recorrido triunfal: Lérida! Está el hombre sonriente. No es para menos...”. Es así como con la presentación directa del enunciado al público, y con el uso de la tercera persona del plural, reforzando la dimensión homodiegética, se construye la convicción en el espectador de que está asistiendo directamente al transcurrir de los hechos. Hemos de señalar al respecto que esta idea resulta fundamental puesto que la película pretende dar cuenta de la transformación económica por la que atraviesa el país en este período conocido como desarrollista, una etapa en la que los empresarios inician un proceso de mecanización que contribuye a lavar la imagen externa de España, por mucho que este enjuague proceda de la explotación de los valores arcaicos y las peculiares condiciones de vida de sus habitantes.

Por otra parte, prosiguiendo con este rastreo de la presencia de la voz over en la obra nechesiana, nos encontramos con títulos que, aunque forman parte de este grupo de documentales expositivos del cineasta, presentan unas características, desde el punto de vista formal, que difieren de lo estudiado hasta el momento y que introducen nuevas posibilidades de lectura desde un punto de vista narratológico. Así, nos hallamos ante tres películas: Ayudaos los unos a los otros (1960), Analiza tus tierras (1960) y Ordeña bien (1960) que parten de un axioma común. Ciertamente, un narrador cinemático, por medio de estos tres enunciados de carácter apelativo imperativo, se dirige, por una parte, a todos los receptores reales, pero muy particularmente a un narratario diegético que identificamos con los agricultores y ganaderos que vehiculan la acción. Que esto es así lo confirma el hecho de que, complementando a la voz over, que enseguida 
toma las riendas de la historia, varios planos, algunos de ellos subjetivos, como este que se muestra en la imagen (Figura 3), dan cuenta de unos textos que solicitan claramente la atención del protagonista, mientras que en otros se informa a los ganaderos de los buenos resultados que puede entrañar una correcta praxis en el ordeño de las vacas (Figura 4).
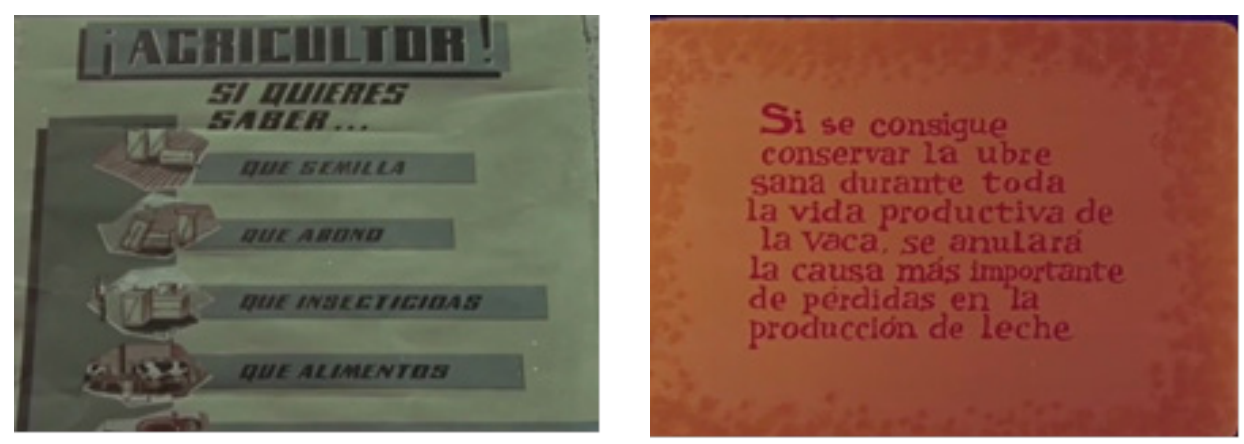

Figura 3. Analiza tus tierras (Neches, 1960)

Figura 4. Ordeña bien (Neches, 1960)

Sin embargo, habría que precisar que los cauces formales elegidos para transmitir el mensaje son diferentes en unos y otros casos. Así en Ayudaos los unos a los otros y Analiza tus tierras Neches recurre a las leyes de la ficción para mostrar, conducidos en todo momento por la voz over, unos acontecimientos que han sido preparados para ser filmados. El cineasta, siguiendo la regla básica de cine clásico, en la que cualquier elemento queda supeditado a la historia, introduce al espectador en una realidad ficcionalizada dentro de la cual los actores — no profesionalesfuncionan como vehículos mudos — puesto que en ningún momento se les da voz - cuyas acciones vienen a concluir en un mensaje moralizante que, transgrediendo lo puramente agropecuario, se empapa de una importante carga propagandística referida a los buenos comportamientos sociales que se esperan de hombres y mujeres ejemplares. Ordeña bien, por su parte, se centra en la descripción de los nuevos procedimientos que son necesarios 
para la obtención correcta de la leche, atendiendo a una realidad, no ficcionalizada, en la que la voz narrativa desempeña una labor formativa.

\section{2. Polifonía narrativa en los documentales reflexivos de Neches}

Hablar de documentales reflexivos significa referirnos a estrategias que, de alguna manera, quebrantan las concepciones que, por norma, podríamos asociar a las características del documental. Significa, por tanto, adentrarnos en un espacio escritural en el que se introducen fisuras, giros o cambios inesperados que nos obligan a centrar nuestra atención, no tanto en la historia, sino en cómo se cuenta esa historia. Para Nichols:

La representación del mundo histórico se convierte, en sí misma, en el tema de meditación cinematográfica de la modalidad reflexiva [...] Mientras que la mayor parte de la producción documental se ocupa de hablar acerca del mundo histórico, la modalidad reflexiva aborda la cuestión de cómo hablamos acerca del mundo histórico [...] Los textos reflexivos son conscientes de sí mismos no solo en lo que respecta a la forma y estilo, como ocurre en los poéticos, sino también en lo tocante a estrategia, estructura, convenciones, expectativas y efectos (1997: 93).

Atendiendo a lo expuesto con anterioridad, podremos comprobar en lo que sigue cómo Neches, en estos documentales de tipo reflexivo, desplaza el centro de atención del modo en el que el cine copia la realidad al modo en el que el cine nos hace creer que copia la realidad, utilizando, con la finalidad de suscitar en el espectador la convicción de que lo que se está narrando es verdad, técnicas ampliamente consagradas por el cine para generar el efecto de objetividad perseguido como enseguida veremos.

Podríamos comenzar con el análisis de El monasterio contesta 
$(1960)^{19}$. Se trata de una película cuyo enigmático título nos exige pensar en un proceso narratológico que está siendo subrayado por la propia frase que intitula el filme porque esta crea en el espectador la necesidad de saber qué y a quién contesta el monasterio, a la vez que se reviste de un protagonismo esencial a esta notable construcción arquitectónica. Así lo demuestra el hecho de que un número importante de los planos que se dan cita en el comienzo del filme se destinan a detallar la grandeza de tan representativo edificio. Por otra parte, un narrador autodiegético, que responde a la categoría de narrador insertado según Kolozloff (1988: 97$99)^{20}$, construye un discurso, no exento de una importante carga ideológica, encaminado a mostrar la historia que encierran unos muros que, con su perdurabilidad y resistencia, atestiguan el pasado legendario de nuestra nación. José Neches opta, en este caso, por adscribirse a las posibilidades formales que le brindan los llamados géneros del yo para dejar constancia de lo vivido a través del valor testimonial que nos ofrece el protagonista con la escritura de un diario que se convierte en la manifestación textual de la propia experiencia. La cámara parece entregarse a los designios de la voz over que, aparentemente, lidera la acción. Efectivamente es ella la que, no solo dota de sentido al misterioso título del filme, sino que encauza el relato como se puede comprobar:

El Monasterio de la Santa Espina fue en otras épocas lugar de veneración y culturas, señor de jurisdicción, poseedor de cuantiosa fortuna, y aquí está todavía, respondiendo, contestando

\footnotetext{
${ }^{19} \mathrm{La}$ fecha que se recoge en el texto para hacer referencia al año de realización de la obra es la propuesta por el Departamento del Servicio de Publicaciones, desde el área de Archivos, Biblioteca y Mediateca del Ministerio de Agricultura y Pesca, Alimentación y Medio Ambiente. Sin embargo, creemos que debe tratarse de un error puesto que en el interior del filme aparece una placa conmemorativa de la visita del Caudillo al Monasterio de la Santa Espina en la que consta 1969 como el año de dicha visita. Con lo cual deducimos que la realización del filme no puede ser anterior a la fecha que aparece en dicha placa.

${ }^{20}$ Es un narrador que comienza a narrar después de que la historia ya ha empezado y que aparece en imágenes en el acto de la narración.
} 
al paso del tiempo y de la vida. Yo, vuelvo a decir, no entiendo de estilos, pero algo muy trascendental he aprendido ya aquí, y es que, en otras épocas, otros hombres idearon y construyeron cosas muy grandiosas y bellas, y sobre todo, he aprendido que la vida, con toda su hermosa tarea, es una herencia, un mensaje que los hombres se van trasmitiendo, y cuando contemplo el monasterio, él me contesta y me da fe de esta continuidad. Si así es.

Sin embargo, este narrador autodiegético, súbdito de una instancia extradiegética superior, que está destinado a contar su experiencia como alumno de la Escuela de Capataces Agrarios, declina, en ocasiones, su poder dando paso a otra figura narrativa que se cuela por los intersticios del texto. Se trata de un narrador cinemático que impone una mirada enunciadora, desprendida de la voz off, para señalar la presencia en el texto de tres imágenes; efectivamente, tres fotografías ocupan la parte derecha del encuadre, y parecen despertar cierta nostalgia en el protagonista (Figura 5). Después, mediante un corte de montaje, esta mirada enunciativa subraya la importancia de esas fotos que configuran un triángulo en cuyos vértices destaca la presencia de aquellas mujeres que son significativas — así hemos de suponerlo por el plano detalle que se les dedica — en la vida de este joven (Figura 6), mujeres que sostienen al hombre en los momentos importantes de su vida cumpliendo con esa función reproductora y aglutinadora propia de los idearios patriarcales $\mathrm{y}$, por ende, de los franquistas.
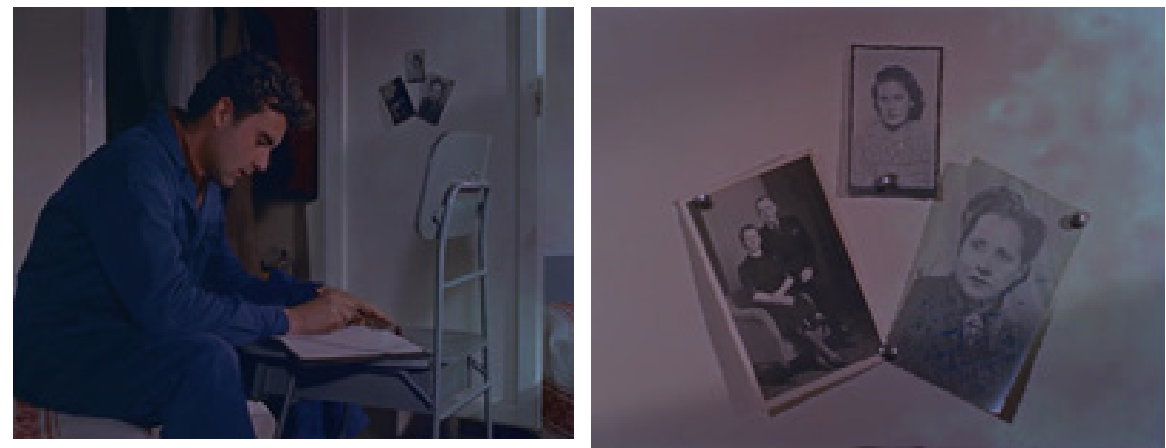

Figuras 5 y 6. El monasterio contesta (Neches, 1960) 
De esta manera se apela a esa sensibilidad femenina, opuesta al intelecto masculino, destinada a favorecer la unidad familiar promulgada por el Nuevo Régimen como uno de los pilares fundamentales de la sociedad. Tengamos en cuenta que la presencia de la mujer en este espacio sería del todo imposible si no fuera por la irrupción en la diégesis de estas imágenes fotográficas, puesto que se trata de un lugar, el Monasterio de la Santa Espina, que acoge entre sus muros a aquellos varones interesados en obtener un título al que las mujeres no podían acceder. Esta idea queda constatada con la presencia en el filme de unos planos en los que los estudiantes - hombres todos ellos, como se puede apreciar- recogen sus diplomas después de haber superado las pruebas correspondientes (Figura 7).

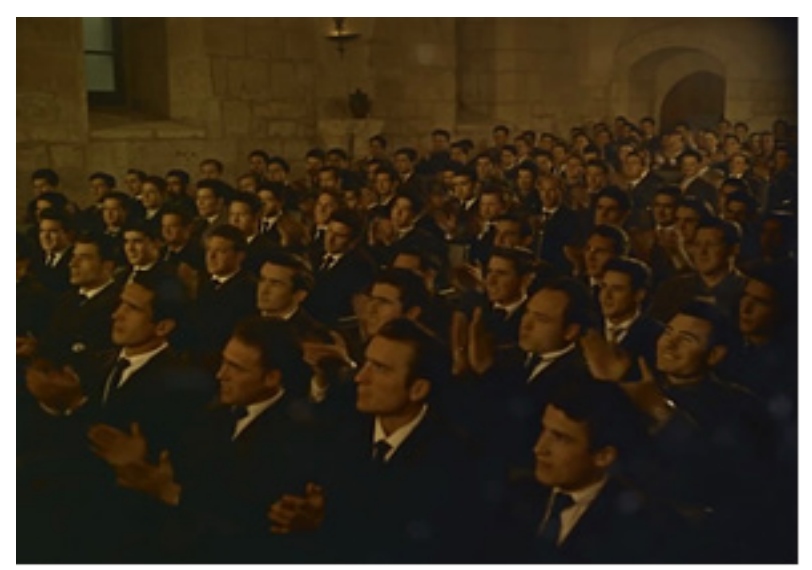

Figura 7. El monasterio contesta (Neches, 1960)

En todo caso, es a través de la escritura del diario, cómo el protagonista —al que, por cierto, en ningún momento se le designaproyecta sobre el texto su experiencia personal en esta Escuela de Capataces, de manera que el receptor puede empatizar con unos hechos que percibe como reales, aunque estén ficcionalizados. Y es que, como muy bien explica el profesor Pozuelo Yvancos, "la literatura [o el cine en este caso] crea simulacros de realidad, representa acciones humanas y realiza un peculiar isomorfismo de manera que los hechos representados 
se asemejan a los acaecidos a personajes que se mueven realmente en el escenario de nuestra existencia" (1993: 18). Por eso, para revestir los hechos de una apariencia veraz, el cineasta injerta en el filme imágenes reales de la visita de Franco y su esposa al Monasterio de la Santa Espina a la vez que el narrador insertado, imbuido de su habitual lirismo, describe tan especial acontecimiento como sigue:

Un día nos visitó el Jefe del Estado. Aquel día estaba más bonito el monasterio. Gentes de otros lugares vinieron aquí para presenciar el acontecimiento. Llegó por fin. Le recibieron con honores. Fue saludando a todo el mundo. Nosotros estábamos formados. Le fueron enseñando las reformas efectuadas. Pasó junto a nosotros. Se fue acercando al monasterio. Entró en él, y, en un claroscuro sorprendente y mágico, se ofreció el interior del templo.

A partir de ahora el narrador cinemático y el narrador insertado se alternan en una suerte de movimientos verbales y descripciones visuales que ofrecen al espectador una panorámica bella y solemne de los muros del monasterio y de lo que estos encierran, incluidas esas voces del pasado que, junto al dorado de las piedras del edificio nos hablan, según este joven narrador, de nuestro pasado histórico.

Otro de los documentales de Neches en el que podemos reconocer la multiplicidad de voces narrativas que domina gran parte de su obra es Plinio Cicerone (1962). Se trata de una película en la que se informa al agricultor de las ventajas que contiene la concentración parcelaria. Es un producto que podríamos denominar mixto por la manera en la que se aborda en él la representación de la realidad. En primer lugar, llama la atención que sea un personaje animado, Plinio Cicerone, el encargado de introducir al espectador en un mundo que se pretender mostrar como real, de tal manera que el pacto pragmático que regula su construcción es el de la ficción, no el de la realidad. El receptor real asiste entonces a la irrupción 
en la pantalla de un conejito muy simpático, Plinio, que se descubre ante él de la siguiente forma: "Soy Plinio, un conejo joven, como ustedes podrán apreciar, pero con la suficiente experiencia como para saber mucho del campo" (Figura 8).

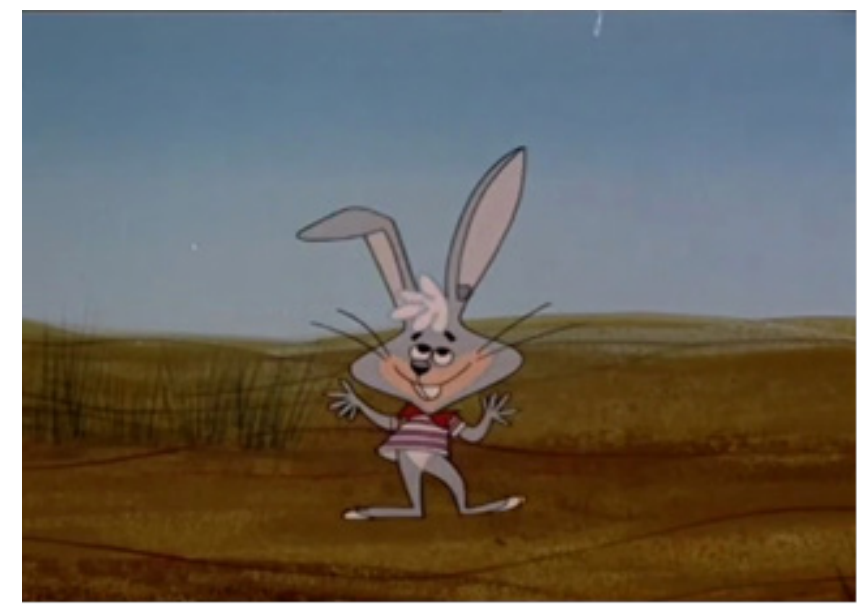

Figura 8. Plinio Cicerone (Neches, 1962)

El protagonista, sin duda, es deudor del mítico Bugs Bunny, creado por Leon Shelesinger, veinte años antes de la realización de este filme, para la Warner Bros. Al igual que su antecesor, el vivaz conejo de Neches, desarrolla una personalidad burlona y desafiante mediante la cual muestra su inteligencia y su sentido común. Del mismo modo que Bugs Bunny, Plinio Cicerone tiene problemas con otras figuras antagonistas como Peporro, un agricultor "tan bruto [según este particular narrador] que ni siquiera sabe lo que es la concentración parcelaria”, hecho que provoca la humillación y la burla de Plinio con respecto a su opuesto. Nos encontramos así con un narrador homodiegético que, desde su categoría de narradorpersonaje, interpela por igual a los receptores reales y a los narratarios que aparecen en el filme. En efecto, la película plantea una representación en abismo, mediante la cual interviene el narrador cinemático, para dar cuenta de la presencia de unos actores reales que asisten, desde el interior de la diégesis, a la proyección de la misma película animada que puede 
ser visualizada por los receptores reales. Es decir, el narratario encarna en sujetos que pueden habitar también el mundo real. De hecho, esta circunstancia acaba resultando esencial para que el pacto de verosimilitud funcione $y$, en consecuencia, para establecer la deseada comunicación con el espectador. Se instaura así un discurso metacinematográfico que tiene su continuidad en un momento posterior del filme, justo cuando Plinio proyecta en una pantalla cinematográfica un documental, en este caso expositivo, a través del cual, un narrador heterodiegético formula, durante ocho minutos, de los doce que dura esta película, la posibilidad de vivir trabajando con "bienestar y alegría" si las pequeñas propiedades agrícolas diseminadas se concentran (Figura 9).

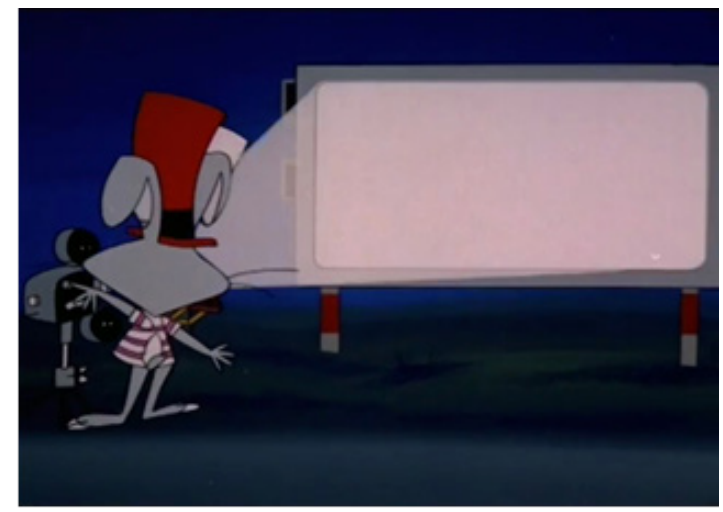

Figura 9. Plinio Cicerone (Neches, 1962)

Se atiende, sin ninguna otra pretensión, a un problema agropecuario del que el Ministerio de Agricultura venía ocupándose desde hace ya algún tiempo, y a las ventajas que supone la concentración parcelaria, tales como la posibilidad del crédito agrícola tras la inscripción de las propiedades en el registro oficial. La voz del narrador concluye con las siguientes palabras: "No habrá disputas y riñas entre colindantes. El labrador se siente ahora seguro y feliz; aumentará su producción y los beneficios serán mayores. La vida, no cabe duda, merece la pena. ¿O no es esto una nueva forma de 
vida?". Entonces, tras un corte de montaje, nuestro protagonista animado aparece de nuevo en escena interpelando a los receptores reales, activando así el contracampo heterogéneo, valiéndose de su peculiar sentido del humor, con una pregunta retórica referida a la película que acaba de proyectar.

Para confirmar que la elección de esta categoría documental no es casual en la obra de Neches, queremos concluir este apartado con el análisis de otro de los filmes que la representan, nos estamos refiriendo a La horas de la tierra (1965). El objetivo fundamental de esta cinta, desde un punto de vista puramente didáctico, es trasladar al espectador la labor que realizan los Agentes de Extensión Agraria y de Economía Doméstica en las zonas rurales durante las diferentes estaciones del año. Sin embargo, especialmente en esta película, se pone de manifiesto que los límites del documental son tan inciertos y tan nebulosos como los de la propia ficción, por mucho que Nichols señale que el realismo documental no es el realismo de la ficción (1997: 217 y ss.). Es así cómo Neches nos propone en este gesto documental una realidad ficcionalizada que "nos permite — como explica Breschand - experimentar las conexiones y las ausencias que son las nuestras, que nos animan y que fundan nuestros sueños" (2004: 71). Por eso la película comienza con un plano cuyo protagonista es un reloj, que se recorta sobre un fondo negro, sobre el que se van impresionando los títulos de crédito mientras las manecillas y el sonido de las campanadas marcan las horas. Esta imagen, que de alguna forma hace referencia al título de la película pero que, en ninguna medida, suscita ninguna aclaración sobre lo que está por llegar, devine en una panorámica ascendente que describe un paisaje natural en el que predominan los colores otoñales, algo que confirma la voz de un narrador heterodiegético con posterioridad diciendo así:

Es el otoño, el tiempo dorado, cuando la naturaleza va cediendo su algarabia, su signo radiante; cuando todo adquiere un aspecto más reposado, más sereno, más tranquilo; cuando un 
aire especial, un color especial, envuelve el paisaje y las cosas dotándolo todo de una leve tristeza, de una cierta melancolía.

Tras oírse la palabra melancolía, la cámara recoge en el encuadre al protagonista del filme, el Agente de Extensión Agraria. Su chapa identificativa y la presentación del narrador lo delatan. Ensimismado, mira el paisaje que define a la comarca que le ha sido asignada por el Servicio de Extensión Agraria con la finalidad de ayudar a los campesinos del lugar. Tanto las imágenes como el narrador describen en lo que siguen las labores de construcción de la Agencia, realizadas por el equipo del SEA, y las relaciones que comienzan a establecer los agentes con el campesinado. En determinadas ocasiones - como el momento en el que aparece en escena la Agente de Economía Doméstica - el protagonista toma la palabra entablando un breve diálogo con otros actantes del relato. Sin embargo, el carácter reflexivo del filme se manifiesta en tanto en cuanto la representación de las estaciones se corresponde con una suerte de alegorías que conviven con imágenes que podríamos definir como reales. Así, un encabalgamiento sonoro, que revela las notas de un violín, da paso a la figura del otoño, un anciano cubierto de hojas que, junto al citado instrumento musical, se presenta ante el joven Agente de la siguiente forma: "Ya sé que estás triste, hombre, lo comprendo, es para estar algo triste, desanimado, cosas de la tierra, cosas de la agricultura, cosas de los hombres. Yo soy el otoño y comprendo tu tristeza porque conozco la amargura de las cosas, la melancolía de la vida" (Figura 10). 


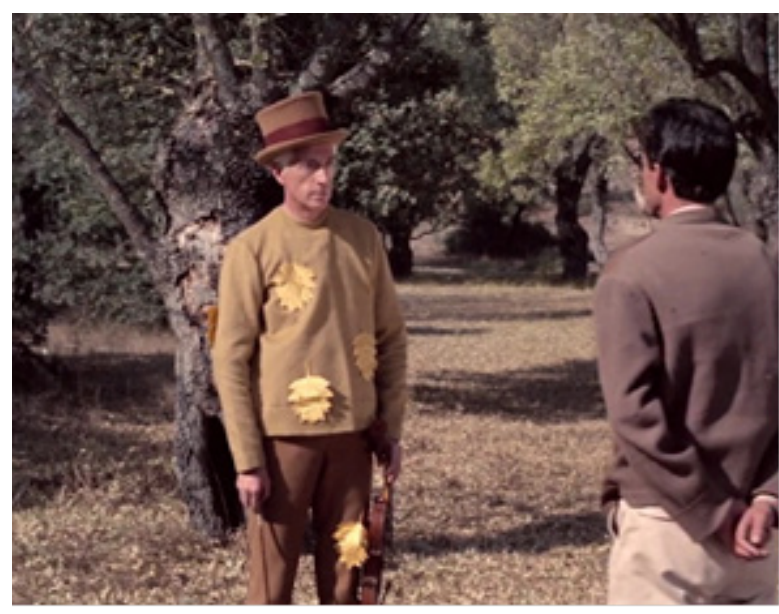

Figura 10. Las horas de la tierra (Neches, 1965)

De igual forma, el invierno, precedido por el paisaje nevado que describe la cámara y la voz del narrador, que cuenta con cierto lirismo cómo esta estación es recibida por el pueblo, aparece en escena a partir de la ensoñación del Agente de Extensión Agraria que escucha en su sueño las voces del otoño, las de los campesinos con los que se entrevista, y hasta la del propio narrador heterodiegético quien, por unos instantes, pasa a formar parte de la diégesis puesto que su voz resuena como un eco del pasado en la cabeza del protagonista. Esta polifonía sonora, que retumba en su cerebro, cesa a consecuencia de un golpeteo en la puerta que parece redimirlo de esa extraña somnolencia. Sin embargo, el espectador es consciente de que el sueño continúa cuando el joven abre la puerta y tras ella aparece una segunda alegoría que representa el invierno. Su iconografía se corresponde con una especie de anacoreta, con sombrero y bufanda, sobre el que se cierne una espesa nevada mientras atiende a estas extrañas palabras del protagonista ${ }^{21}$ : ¿Qué es lo que vienes a decirme,

\footnotetext{
${ }^{21}$ La película parece establecer un guiño intertextual que hace referencia a la película Qué bello es vivir (Capra, 1946) en la que un ángel de la guarda, día de Nochebuena, muestra al protagonista cómo sería la vida en su pueblo si él nunca hubiera existido.
} 
frío, largo y cruel invierno?". A lo que el peculiar personaje contesta: "Vengo a decirte cosas tristes, cosas amargas. Tienes razón, soy largo, tremendamente largo, parece que no voy a acabarme nunca. Sí, soy como las amarguras y el dolor, que parece que nunca se van a acabar". Entonces, el protagonista, cogiéndolo de la mano, lo invita a pasar, y después, un corte de montaje, devuelve al joven a su realidad. El narrador cinemático se inscribe de nuevo en el texto a partir de un plano en el que se muestra un paisaje nevado que no se corresponde con la mirada de ningún personaje y que sirve de transición entre el mundo onírico del protagonista y el mundo real de los personajes de la diégesis. Inmediatamente después, las palabras del narrador heterodiegético, que vuelve a reconducir este documental ficcionalizado, introducen al espectador en el ambiente navideño que viven las gentes de la comarca de esta manera: "Sin embargo, en la Navidad, el frio y la nieve forman parte de un mundo de alegría". A partir de este instante, el narrador adquiere un carisma muy particular, pues parece que recurre a las peculiaridades narrativas del cuento infantil, estableciendo un discurso marcado por una presentación, un nudo y un desenlace, para informar a los receptores reales de cómo los personajes de la diégesis deciden formar una cooperativa agrícola. Veámoslo:

En el pueblo se formó aquellos días una especie de revuelo, y aquel revuelo era recogido y ampliado por las mujeres ¿Qué les pasaba a las mujeres del pueblo? Es decir, ¿qué les pasaba a los maridos? Iban a cenar tarde, del trabajo se marchaban al bar y a la Hermandad de Labradores. Algo estaban maquinando, y icasi sin verlos en todo el día! Y hasta las novias sufrían las consecuencias de esto. Hablaban de formar una no sé qué, una cooperativa ¿Qué era eso de la cooperativa?

Sin solución de continuidad y después de haber terminado la historia, este mismo narrador explica cómo, sujeta a las horas de la tierra, la primavera llega a los campos de la comarca, una primavera que encarna 
en la figura de una muchacha, que evoca a la protagonista de La primavera de Boticelli (1480), y que es observada a través de una mirada enunciadora que recoge a la joven y al Agente de Extensión Agraria en un plano de características singulares, pues parece responder a una apertura en iris, que podría corresponderse con el objetivo literal de la cámara, subrayando así su presencia, en cuyo interior se sitúan ambos personajes (Figura 11). De esta forma, el texto da cuenta de la presencia del narrador cinemático que se inscribe en el relato a partir de un ejercicio puramente formal.

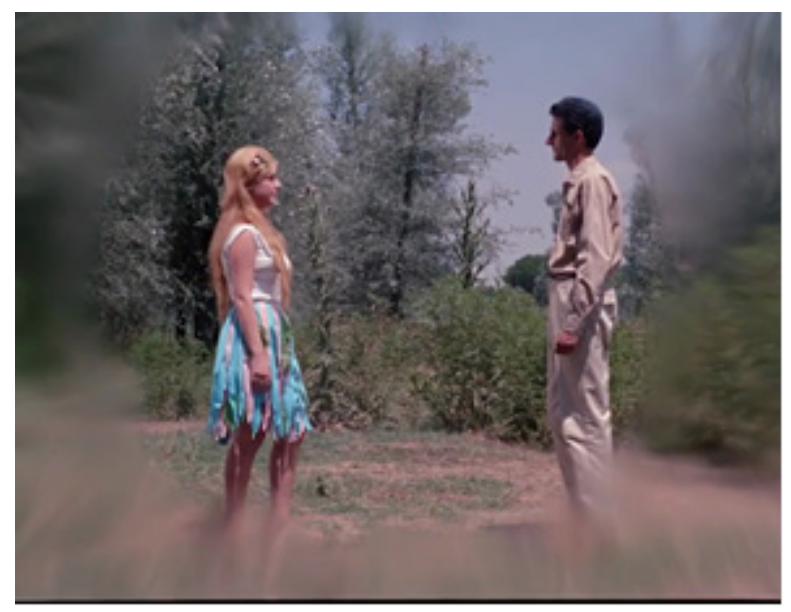

Figura 11. Las horas de la tierra (Neches, 1965)

\section{RECAPITULANDO}

El estudio de la obra de José Neches, como factor decisivo en la comprensión del documental rural en España, obliga a incluir en su análisis aspectos que traspasan los datos económicos, políticos y sociales. Las páginas que anteceden nos llevan a concluir que los documentales de Neches, aunque sujetos a una importante carga ideológica a la vez que pedagógica, muestran las marcas de un tejido cultural, político y social que hacen de ellos una herramienta más que aconsejable en las investigaciones para la recuperación de nuestra memoria colectiva, a la vez que proponen 
una escritura fílmica en la que se hace necesario detenerse por la complejidad de las propuestas plásticas que contiene.

Abordados, en este caso, desde una perspectiva narratológica, su análisis nos ha permitido constatar cómo las voces narrativas proponen una ordenación y sistematización de los acontecimientos que viene condicionada por algunas de las vías en las que el género documental ha encontrando acomodo. Así, nos encontramos con documentales puramente expositivos, en los que la voz de un narrador heterodiegético cumple con su función más clásica, pero también con otros de carácter reflexivo en los que se produce una polifonía narrativa, sorprendentemente rica, en la que el narrador cinemático se sirve de procedimientos formales, como la enunciación, para dejar constancia de su presencia y para reflexionar de manera independiente sobre las imágenes. Este hecho, como ya se ha visto, alcanza una consecuencia inmediata en el modo en el que la carga ideológica contenida en la obra de José Neches es recibida por el espectador. Así mismo, hemos podido observar cómo la variedad en el uso de la voz over se traduce, no solo en dar a conocer o profundizar en los conocimientos relacionados con el mundo agropecuario, sino en establecer mecanismos, en algunos casos procedentes de la ficción, a través de los cuales se adquiere la confianza necesaria entre el emisor y el receptor, un pacto de verosimilitud, entonces, basado en acertados mecanismos narrativos tales como el uso de la voz yoica, la introducción de un lenguaje metacinematográfico, o la intromisión de un narrador-reportero - $\mathrm{O}$ narrador-personaje - quien, mediante la función enfática del discurso que desarrolla, incrementa la relación entre narrador y narratario.

\section{REFERENCIAS BIBLIOGRÁFICAS}

BAJTIN, M. (1991). Teoría y estética de la novela, Helena S. Kriúkova y Vicente Cazcarra (trads). Madrid: Taurus. 
BORDWELL, D. y THOMPSON, K. (1997). El arte cinematográfico. Barcelona: Paidós.

BRANIGAN, E. (1984). Point of View in the Cinema: A Theory of Narration and Subjectivity in Classical Film. New York: Mouton.

BRESCHARD, J. (2004). El documental. La otra cara del cine. Barcelona: Paidós.

ECO, U. (1987). Lector in fabula. Madrid: Lumen.

GARCÍA BARTOLOMÉ, J. M. (2009). "Prólogo". En El servicio de Extensión Agraria. Vivencias, recuerdos y vigencias, 15-19. Madrid: Ministerio del Medio Ambiente y Medio Rural y Marino. GARCÍA JIMÉNEZ, J. (1993). Narrativa audiovisual. Madrid: Cátedra.

GAUDREAULT, A. y JOST, F. (1995). El relato cinematográfico. Barcelona: Paidós.

GENETTE, G. (1989). Figuras III. Barcelona: Lumen.

GÓMEZ BENITO, J. (2015). "La mujer en la agricultura tradicional. Una mirada desde la historia y la sociología visual”. En Jornaleras, campesinas y agricultoras. La historia agraria desde una perspectiva de género, 307-357. Zaragoza: Monografías de Historia Rural 11 / SEHA.

GÓMEZ TARÍN, F. J. y PAREJO, N. (coords.) (2013). Discursos y narraciones en el documental rural: el marqués de Villa-Alcázar. La Laguna (Tenerife): CAL Cuadernos Artesanos de La Latina / XX.

FRIEDMAN, N. (1955). "The Point of View in Fiction: The Development of a Critical Concept". PMLA XX, 1160-1184.

HENDERSON, B. (1983). "Tense, Mood and Voice in Film". Film Quarterly (Otoño), 4-17.

ISER, W. (1987). El acto de leer. Madrid: Taurus.

JAUSS, H. R(1977). Ästhetische Erfahrung und Literarische Hermeneutik. Munich: Fink. [Trad. esp. Experiencia estética y hermenéutica 
literaria: Ensayos en el campo de la experiencia estética. Madrid: Taurus, 1986.]

KOZLOFF, S. (1988). Invisible Storytellers. Berkeley: University of California Press.

(2013). "Algunas cuestiones sobre el mostrar y el decir". Cinema Comparat/ive Cinema I.3, 38-48.

MONTERDE, J. E. (2001). "Realidad, realismo y documental en el cine español”. En Imagen, memoria y fascinación. Notas sobre el documental en España, 15-26. Madrid: Ocho y Medio (Libros de cine).

NICHOLS, B. (1985). “The Voice of Documentary". En Movies and Methods. Volumen II. Berkeley: University of California Press. (1997). La representación de la realidad. Cuestiones y conceptos sobre el documental. Barcelona: Paidós.

ORTEGAARJONILLA, E. (ed.) (2017). De cultura visual y documentales en España (1934-1966): la obra cinematográfica del marqués de Villa Alcázar. Granada: Editorial Comares.

PLANTINGA, C. (1997). Rethoric and Representación in Nonfiction Film. Cambridge: Cambridge University Press.

POYATO, P. (2013). "La voz narrativa: modalidades de narrador en Los abrazos rotos (Almodóvar, 2009)". Revista Comunicación 1.11, 99-110.

POZUELO YVANCOS, J. M. (1993). Poética de la ficción. Madrid: Síntesis.

STAM, R.; BURGOYNE, R. y FLITTERMAN-LEWIS, S. (1999). Nuevos conceptos de la teoría del cine. Barcelona: Paidós.

VALLEJO, A. (2013). "Narrativas documentales contemporáneas. De la mostración a la enunciación". Cine Documental 7, 7-29.

ZUNZUNEGUI, S. (2001). Robert Bresson. Madrid: Cátedra.

Recibido el 7 de febrero de 2018.

Aceptado el 27 de mayo de 2018. 